\title{
PERAN USAHA MIKRO, KECIL, DAN MENENGAH (UMKM) DALAM PEMANFAATAN INTERNET: STUDI KASUS DI DESA BABAKAN PEUTEUY, KECAMATAN CICALENGKA KABUPATEN BANDUNG
}

\author{
Bayu Kharisma
}

\author{
Fakultas Ekonomi dan Bisnis Universitas Padjadjaran, Jawa Barat, Indonesia \\ Jl. Dipati Ukur No. 35 Bandung, 40132, Indonesia \\ Email: bayu.kharisma@unpad.ac.id
}

\begin{abstract}
The purpose of this research is to optimize the role of MSMEs through the use of the internet as a media of promotion for local economic potential in the Babakan Peuteuy Village, Cicalengka District, Bandung Regency, namely the business of bamboo craftsmen, campsite attractions, tofu and tempeh and veil products by using the website as a medium promotion for various products in the Village of Babakan Peuteuy. The method implemented is through surveys and descriptive analysis. The results of the analysis show that the local economic potential in Babakan Peuteuy village is quite good and creative, and the desire of citizens to carry out entrepreneurial activities is already high, but there are still many problems such as an unprofessional organizational structure, poor business management, the technology used is mostly still traditional, raw materials originating from outside the village, lack of human resources, and an inability to market products online. Therefore, together with village officials have tried to make a website. The existence of the use of internet media information dissemination will be faster and wider reach in increasing sales and marketing of products.
\end{abstract}

Keywords: Small and Medium Enterprise (SME); internet; entrepreneurship.

\begin{abstract}
Abstrak
Tujuan penelitian ini adalah mengoptimalkan peran UMKM melalui penggunaan internet sebagai media promosi untuk potensi ekonomi lokal yang berada di Desa Babakan Peuteuy, Kecamatan Cicalengka Kabupaten Bandung yaitu usaha pengrajin bambu, tempat wisata perkemahan, tahu dan tempe serta produk kerudung dengan memanfaatkan website sebagai media promosi untuk berbagai produk yang ada di Desa Babakan Peuteuy. Metode yang dilaksanakan adalah melalui survei dan analisis deksriptif. Hasil analisis menunjukkan bahwa potensi ekonomi lokal di desa babakan peuteuy sudah cukup baik dan kreatif, serta keinginan warga untuk melakukan kegiatan wirausaha sudah tinggi, namun masih banyak permasalahan seperti struktur organisasi yang belum professional, manajemen bisnis yang kurang baik, teknologi yang digunakan kebanyakan masih tradisonal, bahan baku yang berasal dari luar desa, kemampuan dari sumber daya manusia yang ada kurang, dan ketidakmampuan untuk memasarkan produk secara online. Oleh karena itu, bersama aparat desa telah mencoba untuk membuat website. Keberadaan pemanfaatan media internet penyebaran informasi akan lebih cepat dan jangkauannya lebih luas dalam meningkatkn penjualan dan pemasaran produk.
\end{abstract}

Kata Kunci: Usaha Mikro Kecil dan Menengah (UMKM); internet; kewirausahaan. 


\section{PENDAHULUAN}

Pesatnya perkembangan teknologi informasi dan komunikasi atau yang dikenal dengan istilah Information and Communication Technology (ICT) dan internet telah merambah berbagai bidang kehidupan tidak terkecuali bidang bisnis dan perdagangan (Fensel et al, 2001; Purbo, 2003; Bharadwaj et al, 2013). Dengan adanya internet dan ICT maka proses pemasaran dan penjualan dapat dilakukan kapan saja tanpa terikat ruang dan waktu (Chang et al, 2009; Quaddus \& Xu, 2008). Manfaat dan keuntungan menggunakan ICT di Indonesia adalah untuk media promosi dalam rangka untuk meningkatkan volume penjualan, baik untuk penjualan online maupun konvensional (Supardi \& Dores, 2009; Bharadwaj et al, 2013).

Implikasi dari penyelenggaraan promosi melalui media website, terbukti memiliki pengaruh yang cukup signifikan, dimana para pembeli saat ini dapat memperoleh informasi melalui website tanpa tatap muka (face-to-face). Salah satu daerah yang saat ini sedang dikembangkan promosinya melalui media online adalah Desa Babakan Peuteuy, Kecamatan Cicalengka Kabupaten Bandung. Desa tersebut terletak sekitar $51 \mathrm{~km}$ dari pemerintah Kabupatn Bandung dan sekitar $35 \mathrm{~km}$ dari pemerintah Provinsi Jawa Barat. Desa Babakan Peuteuy mempunyai luas wilayah: 419,47 Ha. Dengan batas wilayah sebagai berikut: sebelah utara berbatasan dengan Desa Dampit Kecamatan Cicalengka Kabupaten Bandung, sebelah timur berbatasan dengan Desa Tenjolaya Kecamatan Cicalengka Kabupaten Bandung, sebelah selatan berbatasan dengan Desa Cicalengka Wetan Kecamatan Cicalengka 
Kabupaten Bandung dan sebelah Barat berbatasan dengan Desa Nagrog Kecamatan Cicalengka Kabupaten Bandung.

Potensi ekonomi lokal di Desa Babakan Peuteuy, Kecamatan Cicalengka, Kabupaten Bandung yang saat ini berkembang antara lain Usaha Mikro, Kecil dan Menengah (UMKM) untuk kelompok pengrajin bambu, tempat wisata perkemahan yang berhasil memanfaatkan tanah carik desa di sebuah bukit yaitu Puncak Suji sebagai tempat perkemahan, produk tahu dan tempe serta kerudung hasil kerajinan masyarakat. Usaha Mikro, Kecil dan Menengah (UMKM) memiliki peran yang sangat penting dalam perekonomian suatu negara, terutama memberi nilai positif pada penyerapan tenaga kerja (Hafni \& Rozali, 2017). Hal ini digambarkan dari kondisi masyarakat yang memiliki unskill labor intensive dapat diserap UMKM sehingga UMKM dapat mengurangi pengangguran pada level masyarakat bawah, namun UMKM yang ada selama ini masih menghadapi berbagai masalah antara lain masalah promosi, pemasaran dan penjualan penjualan produk yang dihasilkan (Hartono \& Hartomo, 2016).

Seiring perkembangan teknologi informasi dan komunikasi maka pemasaran dan penjualan produk-produk melalui pemanfaatan internet saat ini sudah banyak dimanfaatkan. Penjualan dan pemasaran produk melalui dunia maya mempunyai banyak keuntungan, yaitu cakupan yang luas, tidak mengenal ruang dan waktu, dapat dilakukan kapan saja dan dimana saja (Jauhari, 2014). Oleh karena itu, pemanfaatan internet patut dicoba untuk membantu mengembangkan UMKM yang ada di Desa Babakan Peuteuy, Kecamatan Cicalengka, Kabupaten Bandung, 
khususnya terkait dengan promosi Usaha Pengrajin Bambu, inovasi Tempat Wisata Perkemahan, tahu dan tempe serta produk kerudung.

Salah satu masalah utama yang dihadapi oleh di Desa Babakan Peuteuy, Kecamatan Cicalengka, Kabupaten Bandung adalah aspek pemasaran. Pemasaran dengan metode konvensional yang selama ini dilakukan memerlukan biaya tinggi, misalnya membuka cabang baru, ikut pameran, pembuatan dan penyebaran brosur dan sebagainya. Berkembangnya internet menjadi sarana yang efisien untuk membuka jalur pemasaran model baru bagi produk UMKM dalam upaya peningkatan ekonomi lokal. Melalui pemanfaatan akses internet yang dilakukan UMKM, disamping biayanya relatif murah, penyebaran informasi akan lebih cepat dan jangkauannya lebih luas, terutama di Desa Babakan Peuteuy, Kecamatan Cicalengka, Kabupaten Bandung yang memiliki akses terbatas terkait dengan promosi produknya.

Tujuan pengabdian masyarakat ini adalah mengoptimalkan peran Mikro, Kecil dan Menengah (UKMK) Dalam penggunaan internet sebagai sarana promosi potensi lokal antara lain yaitu usaha pengrajin bambu, tempat wisata perkemahan, tahu dan tempe serta produk kerudung.

Waktu pelaksanaan kegiatan lapangan dilaksanakan pada tanggal 9 Januari 2019 sampai dengan 9 Februari 2020 di Desa Babakan Peuteuy, Kecamatan Cicalengka, Kabupaten Bandung. Adapun kelompok sasaran yaitu kelompok pengrajin bambu dan tempat wisata perkemahan, Pengrajin bambu dan tempat wisata perkemahan merupakan potensi ekonomi lokal dan inovasi yang berhasil 
memanfaatkan tanah carik desa di sebuah bukit yaitu Puncak Suji, sebagai tempat perkemahan. Selaini itu, usaha pengrajin bambu, tahu dan tempe serta produk kerudung merupakan Usaha Kecil dan Menengah (UKM) yang diprakarsai dan dikelola oleh masyarakat lokal.

Metode yang dilaksanakan adalah melalui survei dan analisis deksriptif. Metode deskriptif adalah metode yang digunakan untuk menggambarkan atau menganalisis suatu hasil penelitian tetapi tidak digunakan untuk membuat kesimpulan yang lebih luas. Sementara itu, metode penelitian survei adalah penelitian yang mengambil sampel dari satu populasi dan menggunakan kuesioner sebagai alat pengumpulan data yang pokok (Sugiyono, 2016). Penelitian ini dilakukan berdasarkan studi literatur, dengan sumber utama pencarian artikel berdasarkan librari yang ada pada portal Garuda yang dikenal sebagai gerbang penelitian Indonesia dan disediakan oleh Kementrian Riset, Teknologi dan Pendidikan Tinggi Republik Indonesia. Langkah yang dilakukan adalah mengumpulkan literatur, menganalisa literatur yang terkumpul, kemudian mengklasifikan literatur, dan menyimpulkan hasil temuan dari kajian yang diperoleh berdasarkan data-data yang telah diolah.

Dalam menentukan jumlah sampel yang akan diambil pada penelitian ini menggunakan rumus Slovin (Umar, 2008) sebagai berikut:

$$
n=\frac{N}{1+N e^{2}}
$$


$\mathrm{n}=$ Jumlah sampel yang dikehendaki

$\mathrm{N}=$ Jumlah populasi

$\mathrm{e}=$ Batas toleransi kesalahan $10 \%$

Responden dalam penelitian ini terdiri dari masyarakat di desa Desa Babakan Peuteuy, Kecamatan Cicalengka Kabupaten Bandung dengan golongan pendapatan menengah $\mathrm{k}$ eatas, pemilihan golongan menengah ke atas. Pengambilan sampel responden dilakukan dengan perhitungan slovin yang berjumlah sekitar 30 orang.

Berbagai tahapan yang dilakukan dalam mengidentifikasi Desa Babakan Peuteuy, Kecamatan Cicalengka Kabupaten Bandung adalah sebagai berikut: 1). Tahap persiapan: Identifikasi kebutuhan materi promosi untuk media online. 2). Tahap Pelaksanaan: Pembuatan website wisata, website yang dibuat akan mengacu pada website dari hasil penelitian dengan menambahkan fitur video, sosialiasi kegiatan-kegiatan pelatihan kepada para pengelola kampung wisata, melaksanakan pelatihan penulisan feature, melaksanakan pelatihan fotografi, melaksanakan pelatihan administrator website dalam mengisi konten feature, foto dan video. 3). Tahap Evaluasi: Evaluasi atas hasil karya yang dihasilkan dari pelatihan-pelatihan yang dilakukan.

\section{HASIL DAN PEMBAHASAN}

Desa Babakan Peuteuy terbagi atas 5 dusun, dimana setiap dusunnya dipimpin oleh seorang kepala dusun sebagai kepanjangan tangan dari kepala desa dalam menjalankan tupoksinya ditingkat dusun. Setiap dusun membawahi $3 \mathrm{RW}$ 
dengan jumlah keseluruhan 14 RW. Lebih jelasnya dapat dilihat pada Gambar 1.

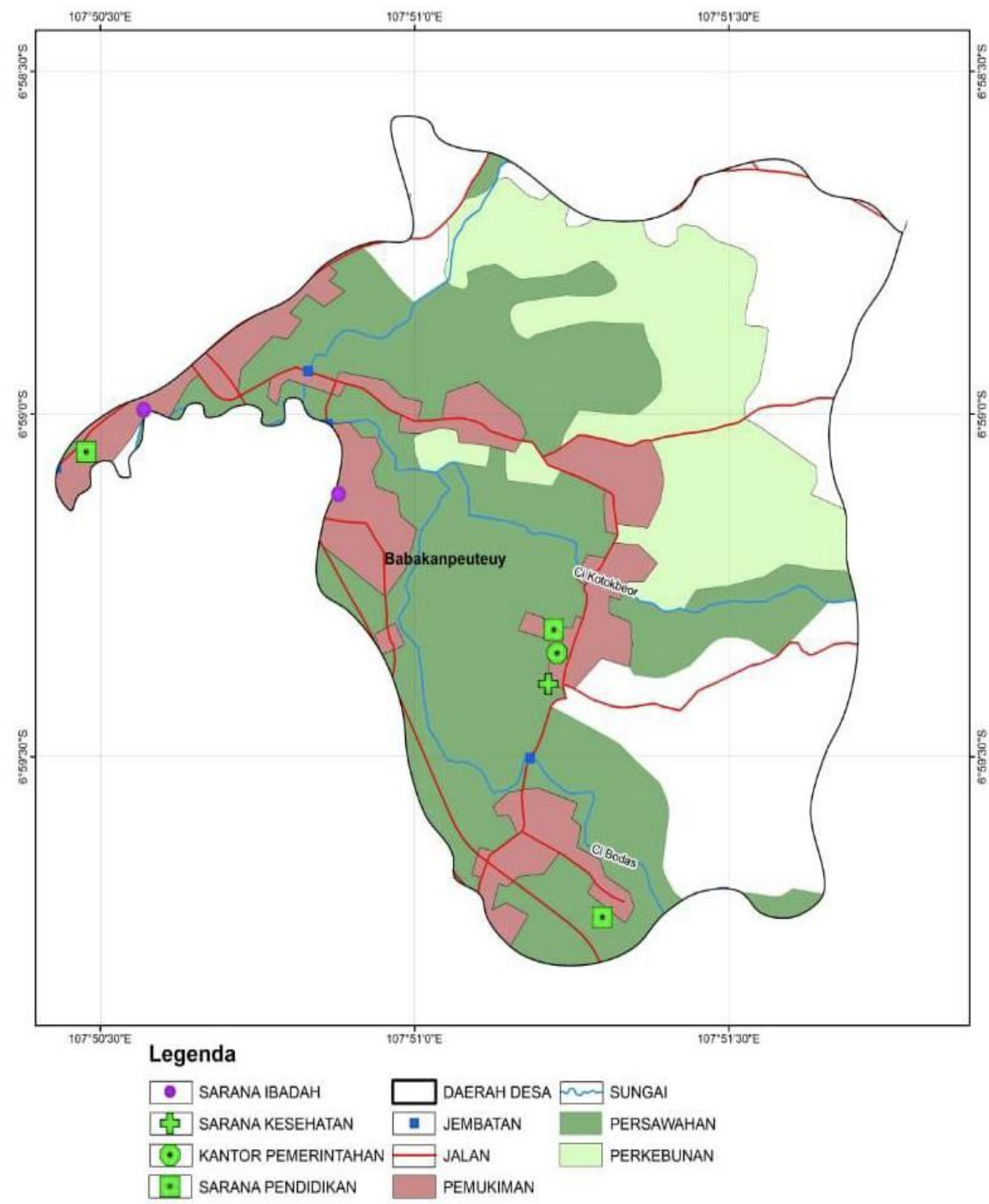

Gambar 1.

Peta Desa Babakan Peuteuy 
Sebelum merencanakan dan merumuskan berbagai program maka hal yang harus dilakukan terlebih dahulu adalah dengan melakukan survei, pemetaan lokasi, serta mengumpulkan berbagai data dan informasi mengenai Desa Babakan Peuteuy. Kegiatan tersebut dilaksanakan melalui koordinasi dengan banyak pihak (stakeholders), seperti Kepala Desa, Karang Taruna, dan berbagai pelaku usaha yang ada di Desa Babakan Peuteuy.

Metode yang dilakukan dalam kegiatan tersebut dapat berupa wawancara, diskusi, dan survei secara langsung ke lapangan. Hasil dari kegiatan tersebut akan digunakan sebagai landasan yang melatarbelakangi pelaksanaan program di Desa Babakan Peuteuy. Kegiatan survei, pemetaan lokasi, serta pengumpulan data merupakan hal yang penting dalam perencanaan program pemberdayaan masyarakat di Desa Babakan Peuteuy. Dengan hasil dari kegiatan tersebut, maka program dapat direncanakan dan dirumuskan secara lebih terarah dan akurat sesuai dengan kebutuhan masyarakat Desa Babakan Peuteuy, sehingga harapannya program yang telah dilaksanakan dapat menjadi langkah awal menuju Desa Babakan Peuteuy yang lebih baik.

Berdasarkan hasil survei dan pengumpulan data tersebut maka permasalahan dan potensi yang ada di Desa Babakan Peuteuy dapat diidentifikasi. Sementara itu, jika ditinjau dari aspek potensi ekonomi lokal maka Desa Babakan Peuteuy merupakan salah satu desa yang memiliki jumlah wirausaha cukup banyak. Produk di Desa Babakan Peuteuy pun dinilai sangat variatif, mulai dari produk kesenian hingga produk makanan. Dalam aspek produk kesenian, Desa Babakan Peuteuy 
memiliki dua rukun warga yang terfokus dalam mengembangkan kerajinan bambu. Bambu diolah sedemikian rupa sehingga nilai jualnya bertambah, seperti menjadi kerajinan surfing board, pulpen, dan figura. Produk kerajinan bambu ini sudah dijual ke berbagai daerah dan negara. Sementara itu, di Desa Babakan Peuteuy juga terdapat banyak wirausaha konveksi kerudung. Salah satu wirausaha konveksi kerudung di Desa Babakan Peuteuy sudah menjual kerudungnya hingga ke mancanegara, salah satunya Malaysia. Selain itu, Desa Babakan Peuteuy juga memiliki pabrik yang terfokus di bidang pangan, yaitu pabrik tahu dan pabrik tempe. Selain pabrik, banyak juga wirausaha rumahan di Desa Babakan Peuteuy yang menjual kue-kue kering. Potensi lain yang ada di Desa Babakan Peuteuy yaitu potensi wisata. Desa Babakan Peuteuy memiliki tempat wisata yang sedang melalui proses pengembangan selama kurang lebih 2-3 bulan, yaitu Puncak Suji. Puncak Suji merupakan tempat wisata yang umumnya digunakan pengunjung sebagai tempat berkemah. Jumlah pengunjung yang datang ke Puncak Suji bersifat fluktuatif, biasanya akan meningkat jika ada tanggal-tanggal penting atau perayaan tertentu seperti tahun baru. Puncak Suji menawarkan pemandangan daerah Cicalengka dan sekitarnya yang menawan. Hal ini menjadi daya tarik tersendiri yang Puncak Suji miliki.

Sejauh ini, potensi-potensi kewirausahaan yang ada di Desa Babakan Peuteuy, terdapat beberapa permasalahan serupa yang dialami setiap pelaku usaha, yaitu belum sistematisnya pengelolaan manajemen bisnis yang profesional, optimalisasi bahan baku dan modal, pengelolaan usaha dengan modal minim, serta belum terpaparnya beberapa wirausaha dengan digitalisasi. Permasalahan tersebut 
merupakan hal-hal yang bisa dikatakan fundamental, sehingga jika permasalahan tersebut dapat diatasi, maka kewirausahaan di Desa Babakan Peuteuy dapat berkembang lebih baik.

Potensi Produk di Desa Babakan Peuteuy. Tahu. Tahu ini memiliki nilai produk yang lebih dari produk sejenisnya berupa bahan yang digunakan $100 \%$ organik dan segar, dikerjakan oleh orang yang profesional, serta harganya terjangkau. Dikarenakan harganya yang terjangkau, produk ini ditujukan untuk warga Desa Babakan Peuteuy dan sekitarnya yang merupakan desa swakarya. Produk tahu ini didistribusikan melalui tukang tahu keliling, warung, dan pasar di Desa Babakan Peuteuy. Agar konsumen tertarik dengan produk tahu ini, maka mereka menjual dengan harga khusus yaitu 1 (satu) tahu seharga Rp.400,00 dan 3 (tiga) tahu seharga Rp.1000,00 serta menjaga harganya tetap stabil. Produksi dan distribusi tahu dilakukan oleh 20 orang pekerja dengan menggunakan alat-alat tradisional. Bahan-bahan yang digunakan dalam produksi antara lain kedelai, kunyit, dan garam. Usaha tahu ini bekerjasama dengan beberapa pihak, antara lain penyedia kedelai, garam, kunyit, dan tukang tahu keliling. Biaya produksi tahu digunakan untuk membiayai pekerja dan membeli bahan baku. Sumber pendapatan produksi tahu didapatkan dari hasil penjualan tahu yang dilakukan oleh tukang tahu keliling dan penjualan di pasar.

Tempe. Kelebihan produk tempe ini dibandingkan yang lain adalah dikerjakan oleh orang yang ahli, bahan yang digunakan alami dan masih segar. Produk ini dijual terutama pada warga Desa Babakan Peuteuy dan sekitarnya. 
Selain pada warga desa, produk ini juga dijual di Pasar-pasar, seperti pasar cicalengka, cileunyi, hingga Pasar Resik Jatinangor. Untuk menarik pembeli, produk ini dipasarkan secara eceran dan harga jualnya diusahakan tetap stabil dan lebih murah dari harga tempe di pasaran. Bahan baku yang digunakan dalam produksi antara lain kedelai, ragi, daun pisang, dan cetakan. Produksi dan distribusi tempe dilakukan oleh 10 orang pekerja dengan menggunakan alat-alat tradisional. Usaha tempe ini bekerjasama dengan beberapa pihak, antara lain penyedia kedelai, garam, dan pasar-pasar disekitar desa. Biaya produksi tahu digunakan untuk membiayai pekerja, transportasi untuk pendistribusian tempe, dan membeli bahan baku. Sumber pendapatan produksi tahu didapatkan dari hasil penjualan tempe yaitu sekitar Rp.65 juta rupiah.

Kerudung CV. GAMMA JAYA GROUP. Produk selanjutnya adalah produk kerudung. Produk kerudung ini memiliki beberapa kelebihan dibandingkan yang lain adalah harganya terjangkau, model bervariasi dan up to date, serta distribusinya luas. Produk ini ditujukan untuk warga muslimah yang memiliki pendapatan menengah kebawah. Produk ini juga didistribusikan di dalam negeri dan luar negeri, di dalam negeri terutama di daerah Jawa Barat, Jakarta (Tanah Abang), Kalimantan, dan Makassar. Di luar negeri, memiliki beberapa outlet seperti di Malaysia (Kuala Lumpur, Sabah, dan Kelantan), Australia, Filipina, dan Brunei Darussalam. Strategi bisnis yang digunakan yaitu menerima pihak reseller tanpa harus memiliki modal awal. Untuk harga produk, kerudung polos dijual dengan harga 8000, dan untuk yang bermotif seharga Rp.15.000,00. Untuk menjaga harga tetap murah, dilakukan dengan cara membagi pabrik produksi agar biaya produksi lebih murah dengan cara 
pemasaran pada distributor besar, toko-toko, dan dijual secara online. Kegiatan yang dilakukan oleh perusahaan ini antara lain produksi, distribusi, analisis pasar, dan controlling, serta menggunakan teknologi yang cukup modern seperti alat pemintal benang dan mesin jahit. Bahan baku yang digunakan dalam produksi antara lain benang, kain, dan sumber daya manusia yang memiliki kemampuan menjahit, mendesain model kerudung, serta analisis bahan, model, dan pasar. Pihak-pihak yang bekerjasama dengan CV ini antara lain reseller, pabrik pemintal benang, desainer, pengusaha luar negeri, asosiasi pengusaha kerudung Indonesia, dan karyawan dari berbagai daerah. Biaya produksi tahu digunakan untuk membiayai karyawan, analisis pasar, membeli bahan baku, dan distribusi dalam negeri maupun luar negeri. Sumber pendapatan produksi tahu didapatkan dari hasil penjualan dan kerjasama dengan reseller.

Kerajinan Bambu. Produk terakhir adalah kerajinan bambu seperti suvenir, bolpoin, figura, piala, gantungan kunci, dan ukir-ukiran. Produk ini memiliki beberapa kelebihan antara lain harganya murah, model dapat disesuaikan dengan keinginan pembeli, kreatif dengan ukiran tradisional dan tahan lama. Produk bisa dibeli minimal empat kwintal, dengan kerajinan bambu polos dijual seharga dua ratus per keping. Produk ini ditujukan untuk Kabupaten Bandung sekitarnya, dan daerah wisata terutama Bali. Produk ini didistribusikan di Floating Market Bandung dan di toko-toko Cinderamata di tempat wisata di seluruh Indonesia seperti Bali, Jakarta (TMII, PRJ), bahkan sampai toko di luar negeri yaitu Australia, Prancis, Inggris, Cina. Produksi dilakukan dengan menggunakan alat tradisional dan alat ukir berupa logam yang dilapisi oleh kumparan tembaga yang dialiri listrik. 
Untuk aktivitas distribusi diluar Kabupaten Bandung dilakukan oleh anggota keluarga dari pihak produsen. Bahan baku yang digunakan adalah bambu dan obat pemutih bambu. Sumber daya manusia pada produksi ini adalah pengukir dan pengrajin bambu. Dalam melakukan produksi kerajinan bambu, bekerjasama dengan penyedia bambu, dan untuk distribusinya dengan pihak-pihak toko cinderamata. Biaya produksi digunakan untuk membiayai karyawan, membeli bahan baku, dan distribusi dalam negeri maupun luar negeri. Sumber pendapatan didapatkan dari hasil penjualan dan kerjasama dengan distributor. Wisata Perkemahan. Potensi terakhir adalah, tempat wisata perkemahan yang berhasil memanfaatkan tanah carik desa di sebuah bukit yaitu Puncak Suji, sebagai tempat perkemahan.

Dalam pembuatan website untuk Desa Babakan Peuteuy ini dimulai tahap persiapan dilaksanakan mulai dari tanggal 10 Januari 2020 di Desa Babakan Peuteuy, Kecamatan Cicalengka, Kabupaten Bandung, Jawa Barat dengan proses adalah mengumpulkan data terlebih dahulu serta informasi mengenai kebutuhan apa saja yang dibutuhkan oleh pihak Wisata Desa Babakan Peuteuy dalam mengembangkan kampung wisatanya. Setelah informasi tersebut dikumpulkan, lalu proses yang selanjutnya dilakukan adalah membuat prototype dari website yang akan dibuat. Selanjutnya dari prototype yang telah dihasilkan kemudian dibuatlah sebuah konsep High Fidelity yang diterapkan pada pembuatan website khususnya untuk Wisata Desa Babakan Peuteuy. Website yang dibuat ini dibangun menggunakan bahasa pemrograman PHP dengan framework yang digunakan adalah Codeigniter. Database yang digunakan dalam pembuatan website ini adalah 
Bayu Kharisma. Peran Usaha Mikor, Kecil, dan Menengah (UMKM) Dalam Pemanfaatan

MySQL. Pembuatan website ini membutuhkan waktu sekitar 3 (tiga) minggu di luar testing dan implementasi. Website tersebut memiliki tampilan seperti pada Gambar 2.

FEBRUARY 5, 2020 | BABAKANPEUTEUY

\title{
Puncak Suj]: Potensi Wisata Desa Babakan Peuteuy
}

Bandung, Sabtu (11/01/2020) - Tau gak sih, Sahabat Peuteuy? Setelah berdiskusi dengan beberapa stakeholders dan melakukan survey lokasi, ternyata Desa Babakan Peuteuy punya tempat wisata, ho! Namanya Puncak Sujj. Pengembangan Puncak Suji sebagai tempat wisata ini terbilang baru, yatu kurang lebih 2-3 bulan.

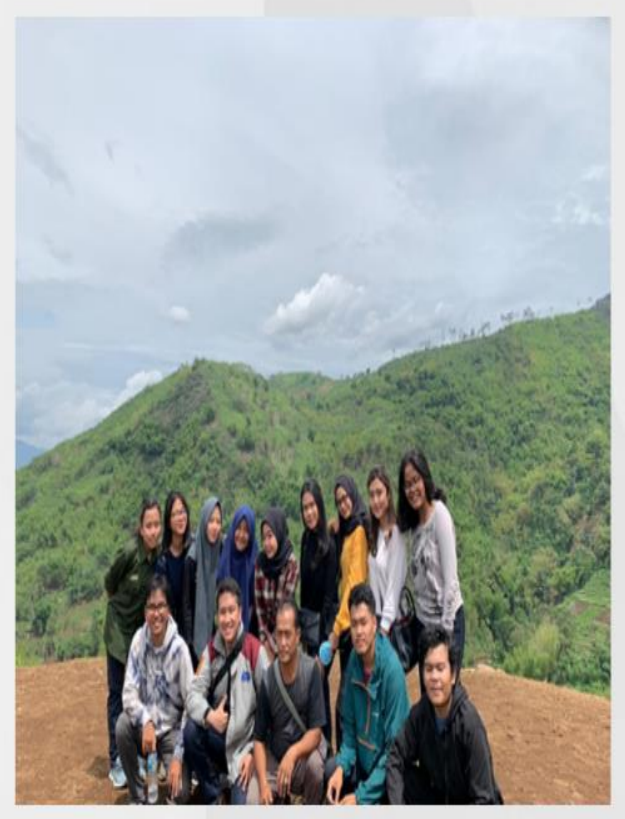

\author{
Post Terbaru \\ Potensi Kewirausahaan Desa \\ Babakan Peuteuy: Konveksi \\ Kerudung, Tahu, Tempe, dan \\ Kerajinan Bambu \\ FEBRUARY 5, 2020 \\ Pemilihan Ketua Karang Taruna \\ Desa Babakan Peuteuy \\ FEBRUARY 5, 2020 \\ Puncak Suj]: Potensi Wisata Desa \\ Babakan Peuteuy \\ FEBRUARY 5, 2020 \\ Kedatangan Perdana di Desa \\ Babakan Peuteuv
}

Gambar 2.

Potensi Produk 
FEBRUARY 5, 2020 | BABAKANPEUTEUY

\section{Potensi Kewirausahaan Desa Babakan Peuteuy: Konveksi Kerudung, Tahu, Tempe, dan Kerajinan Bambu}

\begin{abstract}
Bandung, Kamis-Jumat (16-17/01/2020) - Halo, Sahabat Peuteuy! Seperti yang sudah Mimin Peuteuy ceritakan sebelumnya, Desa Babakan Peuteuy merupakan desa yang sudah mandiri dan dapat mengembangkan potensinya. Hal ini terlihat dari cukup banyaknya jumlah wirausaha yang ada di desa ini. Mulai dari konveksi kerudung,
\end{abstract} kerajinan bambu, hingga bahan pangan seperti tahu dan tempe. Beragam banget, kan, potensinya?
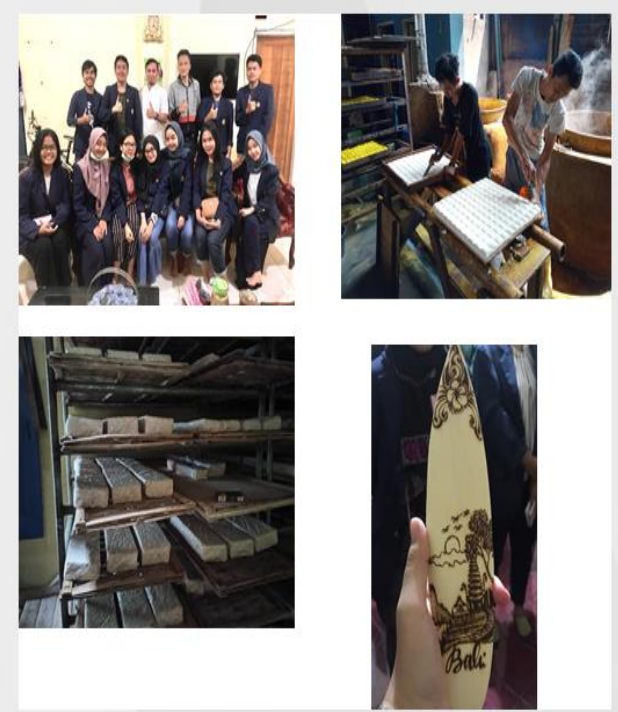

Search...

Post Terbaru

Potensi Kewirausahaan Desa Babakan Peuteuy: Konveksi Kerudung, Tahu, Tempe, dan Kerajinan Bambu FEBRUARY 5, 2020

Pemilihan Ketua Karang Taruna Desa Babakan Peuteuy FEBRUARY 5, 2020

Puncak Suji: Potensi Wisata Desa Babakan Peuteuy FEBRUARY 5, 2020

Kedatangan Perdana di Desa Babakan Peuteuy FEBRUARY 5,2020

\section{Gambar 3.}

\section{Halaman beranda}

Gambar 3 merupakan informasi umum dari keseluruhan informasi yang bisa diakses oleh pengunjung seperti pencarian desa wisata, berita terbaru dari desa wisata, informasi terbaru dari potensi desa wisata. Pada Gambar 2 berisi informasi mengenai berbagai potensi kuliner yang dimiliki oleh desa desa wisata yang ada di 
situs ini. Melalui informasi kuliner tersebut, diharapkan pengunjung akan tertarik untuk melihat profil desa wisata berdasarkan potensi kuliner yang dimiliki. Jika pengunjung tertarik akan suatu info kuliner maka akan diarahkan ke profil desa wisata yang memiliki potensi kuliner tersebut.

\section{SIMPULAN}

Kegiatan pengabdian masyarakat ini telah mencoba untuk memanfaatkan website sebagai media promosi untuk berbagai produk yang ada di Desa Babakan Peuteuy. Bersama aparat desa, tim telah bekerjasama untuk membuat website dan membekali para pengelola kampung wisata, khususnya kamu muda, untuk dapat mengelola web tersebut. Keberhasilan dari promosi melalui website yang sudah dilakukan, masih membutuhkan waktu untuk dapat diukur seberapa besar keefektivitasannya. Namun setidaknya, calon wisatawan dapat memperoleh informasi tentang kampung wisata Desa Babakan Peuteuy.

Hasil analisis yang telah dilakukan berdasarkan survei dilapangan menunjukkan bahwa potensi ekonomi lokal di desa babakan peuteuy sudah cukup baik dan kreatif, serta keinginan warga untuk melakukan kegiatan wirausaha sudah tinggi. Akan tetapi, masih diperlukan edukasi dan pencerdasan pada warga agar usaha yang ada dapat dilakukan secara berkelanjutan. Hal tersebut dapat dilihat dari permasalahan-permasalahan yang terdapat pada usaha-usaha diatas, seperti struktur organisasi yang belum professional, manajemen bisnis yang kurang baik, teknologi yang digunakan kebanyakan masih tradisonal, bahan baku yang berasal dari luar 
desa, kemampuan dari sumber daya manusia yang ada kurang, dan ketidakmampuan untuk memasarkan produk secara online.

\section{REFERENSI}

Bharadwaj, A., El Sawy, O. A., Pavlou, P. A., \& Venkatraman, N. (2013). Digital business strategy: Toward a next generation of insights. MIS Quarterly: Management Information Systems, 37(2), 471-482. https://doi.org/10.25300/MISQ/2013/37:2.3

Chang, J., Song, T., Li, C., \& Song, T. (2009). Modeling E-commerce website quality with quality function deployment. In Proceedings - IEEE International Conference on e-Business Engineering, ICEBE 2009; IEEE Int. Workshops AiR 2009; SOAIC 2009; SOKMBI 2009; ASOC 2009 (pp. 417-422). https://doi.org/10.1109/ICEBE.2009.65

Fensel, D., Ding, Y., Omelayenko, B., Schulten, E., Botquin, G., Brown, M., \& Flett, A. (2001). Product Data Integration in B2B E-Commerce. IEEE Intelligent Systems, 16(4), 54-59. https://doi.org/10.1109/5254.941358

Hafni, R., \& Rozali, A. (2017). Analisis Usaha Mikro, Kecil, dan Menengah (umkm) terhadap Penyerapan Tenaga Kerja di Indonesia. Ilmu Ekonomi Dan Studin Pembangunan, 15(2), 77-96. Retrieved from http://jurnal.umsu.ac.id/index.php/ekawan/article/view/1034/pdf_58

Hartono, H., \& Hartomo, D. D. (2016). Faktor-faktor yang mempengaruhi perkembangan umkm di surakarta. Jurnal Bisnis dan Manajemen, 14(1), 15. https://doi.org/10.20961/jbm.v14i1.2678

Husein, Umar. (2008). Metode Penelitian Untuk Skripsi dan Tesis Bisnis. Jakarta. PT Rajagrafindo Persada

Jauhari, J. (2014). Upaya Pengembangan Usaha Kecil Dan Menengah (Ukm) Dengan Memanfaatkan E-Commerce. Jurnal Sistem Informasi, 2(1), 159-168. https://doi.org/2355-4614

Pemerintah Kabupaten Bandung Kecamatan Cicalengka. "Informasi Desa atau Keluaran". (diakses pada 11 Januari 2020). Tersedia dari https://kecamatancicalengka.bandungkab.go.id/

Purbo, O. (2003). Internet for the masses. International Journal of High-Energy Physics. Retrieved from http://cerncourier.com/cws/article/cern/28900

Quaddus, M., \& Xu, J. (2007). Adoption of e-Commerce: A decision theoretic framework and an illustrative application. In 2007 10th International 
Bayu Kharisma. Peran Usaha Mikor, Kecil, dan Menengah (UMKM) Dalam Pemanfaatan

Conference on Computer and Information Technology, ICCIT. https://doi.org/10.1109/ICCITECHN.2007.4579406

Sugiyono (2016). Metode penelitian kuantitatif, kualitatif dan R\&D. Alfabeta, $C V$.

Supardi, J., \& Dores, V. (2009). Rancang Bangun Collaborative System Pemasaran

Hotel Secara on-Line Dengan Pendekatan Mediator Based. Sistem Informasi (JSI), 1(2), 55-61. 